\title{
From European Federalism to the European Union, Insights of Nobel Prize Laureate, Maurice Allais
}

\author{
Arnaud DIEMER \\ Correspondence: Université Clermont-Ferrand, CERDI, Jean Monnet Excellence Center on Sustainability (ERASME), \\ Postgrowth Institute (PI) - HVL, Norway
}

Received: July 9, 2021 Accepted: September 22, $2021 \quad$ Online Published: November 15, 2021

doi:10.5539/res.v13n4p18 URL: https://doi.org/10.5539/res.v13n4p18

\begin{abstract}
From 1945 to the end of his life, Maurice Allais, Nobel Prize Laureate in Economics (1988), devoted a large part of his work to the European question. As a staunch Unionist, Allais insisted on the fact that, while the threefold freedom of goods, people and capital was necessary to improve the well-being of individuals, it was also a very ambitious goal. Thus, he argued, it was necessary to promote a European federalism on the basis of a scientific criterion: economic democracy — and via an organized method: competitive planning. However, Allais was aware that political integration had to precede economic integration and that economic efficiency could not be ensured without a single currency. He argued that the introduction of the euro had to be accompanied by real monetary reform (credit system, indexation of future commitments, stock markets, international monetary system) in order to regulate the multiplication of financial crises.
\end{abstract}

Keywords: Maurice Allais, Europe, federalism, free market, liberalism, socialism

\section{Introduction}

For more than thirty years, the scientific community has associated the name of Maurice Allais with his pioneering work on the theory of markets and the efficient use of resources (1943) and with the Nobel Prize in Economics he received in 1988. Allais's contributions to economic analysis were in four main areas (Allais, 2001): (1) the theory of general economic equilibrium, (2) the theory of capital, (3) the theory of uncertain choices, and (4) the theory of money, credit and monetary dynamics. Allais $(1943,1952,1994)$ did not hesitate to point out that his work originated in his meditation on that of three great economists: Léon Walras, Vilfredo Pareto, and Irving Fisher. However, as Thierry de Montbrial (2002, p. 453) pointed out about Allais,"One would be singularly reducing the dimension of the character and his work if one were to retain only the theoretical side, as monumental as it is". Following in the long tradition of the French engineer-economists (Dupuit, Colson, Divisia), Allais recalled in The Passion for Research (2001) that it was this direct contact with economic and social realities that decided his career as an economist. As such, his approach was not to start from theory and end up with facts, but rather, to try to extract from the facts the framework without which they appear incomprehensible (Diemer, Nedelciu, 2020). If pure economics needs applied economics, the latter necessarily relies on the former, he reasoned. To understand the interweaving of pure and applied economics in Allais's thinking, we will focus on the aspects of his work relating to European construction. A proponent of what he called competitive socialism (1949c, p. 1), Allais never stopped advocating a non-dogmatic form of economic liberalism (Diemer, 2020). Distinguishing his positions from those of Friedrich Hayek and Milton Friedman by his conception of the role of the state and the system of ownership (factors of production), Allais offered an analysis of European construction that we will break down into two parts. Firstly, we will present his conception of a federal Europe. Secondly, we will return to his analysis of European economic and monetary integration.

\section{European Federalism}

Beginning with his earliest works, Maurice Allais showed a deep commitment to European construction. In a memorandum written on 15 September 1948 entitled, "The European Revolution has to be done", he was already indignant at what he saw as "debilitating" prudence, "frightened" conservatism and "particularistic" nationalism: "There is talk of a united Europe, but the desires remain cautiously on the verbal level. One does not want to see the realities in the face, one glosses over the real problems, one refuses to consider the only measures that can make the European idea something other than a catch-all: the immediate abandonment of certain sovereign rights and the constitution of a supra-national European government" (1948a, p. 4). Allais was convinced that the solution to Europe's economic and social problems involved a European federation. He did not hesitate to present an economic and social draft: "Manifesto 
for the United States of Europe" (1949a), in which he outlined the main principles to be applied (art. 17. Economic Management, art. 18. Income Distribution, art. 19. Social Promotion, art. 20. International Order, art. 21. Monetary Stability, etc.) If the European federation is similar to a union, he argued, it cannot be satisfied with a simple customs union. He pointed out that the lessons of history (Benelux, the International Trade Charter of Geneva and Havana, the Franco-Italian Customs Union, etc.) remind us that it is impossible to overcome obstacles involving opposing national interests other than by creating a supranational government with the competencies to address all questions likely to create opposing interests between the member states.

The rare successes of such experiments (e.g. the case of the German Zollverein, the Italian economic union, the United States, etc.) referred to a particular context (the predominant influence of Prussia for the Zollverein) or to the emergence of a real human will (United States). In Allais's view, the solution of a customs union, apparently simple and non-binding, would thus be "utopian" and only the federalist solution, which advocates the prior and immediate establishment of a political federation, would actually be feasible (Allais, 1949h, p. 7). Allais's work was thus in line with that of Robbins (1937), Streit (1939), Hayek (1939), and Jennings (1940) on federalism, while seeking to go beyond them. He advocated that a federation should become a political order where powers are as decentralised as possible so that the economic is embedded in the political (and cultural): "Our historical task is to make Europe politically and to do so without delay, because on the economic level, the political federation of Europe conditions its economic union, which alone can enable it to rebuild its ruins and raise its living standards" (Allais, 1949h, p. 15).

\subsection{The Rights of the Union and the Member States}

Allais's vision of the federal principle stipulated that the European political community should only be entrusted with those tasks of common interest which it alone could implement effectively. Allais believed that each member state should retain all competencies that were only of a national character and that the state would be able to manage more efficiently itself. First, Allais (1947c, p. 12) outlined the rights to be delegated to the federal Union: (1) the right to regulate monetary conditions, (2) the right to legislate on external and internal trade. This latter principle presupposes that the federation would have the ability to fight against monopolistic forms and customs restrictions (transport tariffs, private trusts, etc.), (3) the right to legislate on the movement of capital, (4) the right to ensure the free movement of the population as the only way to prevent a decrease in welfare and the rise of inequalities, (5) the right to regulate the conditions of production and trade of armaments and atomic energy, (6) the right to regulate communications and to fix tariffs, (7) the right to act on the distribution of rents of scarcity (land rents corresponding to the use of the soil and the production of raw materials and the pure interest of capital) and the power to tax them, (8) the right to levy taxes necessary for the functioning of the Federal Union if the taxation of rents of scarcity were not sufficient, (9) the right to deal with all economic questions relating to associated groups overseas, (10) the supervision of state and federal legislation by a Supreme Court.

In a second stage, Maurice Allais outlined the rights to be left to each nation state as follows: (1) the regulation of certain harmful products (e.g. alcohol), (2) the determination of a social legislation in which each federated state would be free to fix the duration of work as well as its general conditions as long as the salaries were freely fixed at the levels which ensured balance, (3) the establishment of a national social security system. While he deemed this possible, he pointed out that a country with strong protections would necessarily be characterised by lower real wages (Allais deduced a tendency to emigration or immigration), (4) administrative expenditure and public works of local interest, (5) the taxation of any federated state. He argued that this taxation must only be able to affect income from work (wages, salaries and profits) to the exclusion of rents from scarcity (which would be returned to the Federation), (6) the creation of collectivist enterprises. According to Allais, nothing prevented a federated state from creating collectivist enterprises in which its citizens were the shareholders: "There is no opposition between the federal principles of free circulation of goods, capital and men and the collectivist form of ownership of enterprises" (1947c, p. 17). He added, however, that "this collectivist society can only be effective if it is collectively planned" (ibid). For Allais, the essential principles of this distribution of powers were therefore simple: to allow each federated state the maximum amount of freedom and to intervene only in those decisions likely to create difficulties between the federated states. It was not a question of unifying and centralising everything, but rather of preserving all forms of diversity.

\subsection{The Atlantic Union}

However, Allais argued that a federal Europe could only be viable and effective if it succeeded in integrating a wider community of free people, committed to the same ideals of freedom and equity. This larger unity, he reasoned, must include all Western democracies, particularly those of Europe and North America. It appears that the project of the Atlantic Union, advocated by Clarence Streit (1939) in the framework of the Freedom and Union Association and the Committee for the Federal Union of Atlantic Democracies, attracted Allais's attention (Allais, 1949d). According to Streit, the Union of North Atlantic Democracies would be composed of fifteen founding democracies, including the United States, the British Commonwealth (United Kingdom, Canada, Australia, New Zealand, South Africa, Ireland), the French 
Republic, Belgium, the Netherlands, the Swiss Confederation, Denmark, Norway, Sweden, and Finland. It would entail the following: "A Union nationality, a Union armed force, a customs-free regime between the member countries of the Union, a Union currency, a postal system and a communications network common to all the territories of the Union" (Streit, 1939, p. 23).

This project thus aimed to promote a united Federation with a common citizenship, a common foreign policy, and a common monetary organisation (see also Hayek, 1939). It allowed for a suitable transition period for the threefold freedom of movement of goods, capital, and people. For Maurice Allais, this Atlantic Union would be a bulwark between the democratic West and the totalitarian East, the true symbol of a struggle that had to be waged on the economic, social, and ideological levels: "The liberal system will finally win if, while facing the imperative requirements of its security, it proves decisively superior on the triple economic, social and human level of scientific progress and efficiency, of the real increase of man from the material or political constraints that enslave or threaten him" (1960a, p. 14). The Atlantic Union would not be a pseudo-entity dominated by the United States, but a genuine federation organised on a democratic basis (Allais, 1957).

Table 1. Atlantic Union and Democrcy

\begin{tabular}{|c|c|c|}
\hline Country & Deputies & Senators \\
\hline Australia & 7 & 2 \\
Belgium & 8 & 2 \\
Canada & 11 & 2 \\
Denmark & 4 & 2 \\
United States & 129 & 10 \\
Finland & 4 & 2 \\
France & 42 & 4 \\
Ireland & 3 & 2 \\
Italy & 44 & 4 \\
Norway & 3 & 2 \\
New Zealand & 2 & 2 \\
Netherlands & 8 & 2 \\
United Kingdom & 47 & 4 \\
Sweden & 6 & 2 \\
Switzerland & 4 & 2 \\
South African Union & 2 & 2 \\
\hline Total & 324 & 46 \\
\hline
\end{tabular}

Source : Streit (1939, p. 21), Allais (1949d, p. 5)

Taking up the terms of the Draft Constitution drawn up by Streit (1939, 315-324), Allais specified that the legislative power would comprise two chambers: "One elected on the basis of Universal Suffrage, the other on the basis of equal representation of each country on each slice or fraction of slice of less than 25 million inhabitants" (1949d, p. 5). Europe would thus have a majority in both chambers. Such an initiative would in no way hinder the effort of Europeans to establish a European federation. On the contrary, it would facilitate the implementation of a European federation by transposing it into a broader plan. In order to judge the value of federalism relative to any other system, Allais argued that a "scientific" criterion was needed. Economic democracy would be the economic counterpart of political democracy in the political sphere.

\subsection{Economic Democracy}

The criterion of economic democracy was to be analysed at length in two of Allais's manuscripts entitled The Economic Aspects of Federalism and Democracy and Totalitarianism, written in 1947 and 1950, respectively. For Allais, democracy was much more than a simple political method (a thesis defended by Joseph Schumpeter in his book Capitalism, Socialism and Democracy, 1947, p. 242) and could not be limited to the political domain (Barrère, 2009). In the 1930s, Clarence Streit had already noted that democracy was a system which men, grouped together on the basis of equality, have established to safeguard their individual liberty, that is, they have organised the government of the people, so that their laws apply equally to all individuals, by the people, all having an equal share in the making of laws, and for the people, in order to secure liberty, in the widest sense of the word, equally to all.

For Maurice Allais, democracy appeared as a competitive struggle for power, organised according to certain rules of the game: "It is the competitive struggle for power with all that an effectively competitive struggle entails: freedom of 
expression, respect for individuals, sufficient dispersion of power, a legal order capable of enforcing the fairness of competitive competition for political power and respect for the rules of the game both by the group in power and by the minority groups seeking to achieve it" (1950c, p. 570). Democracy was thus a regime based on freedom of expression (freedom of information and discussion) and the defence of opinions (freedom of speech, freedom of assembly, freedom of the press, freedom of publication). Respect for minorities and individuals was an unalterable principle. The persecution of minorities, even if desired by the majority, could not therefore be regarded as democratic, in Allais's view. The balance of power implied the decentralisation of power (anything that tends to disperse power is favourable to democracy) and the independence of economic and political power. Furthermore, Allais argued that democracy can only exist if there is a legal order that can enforce fairness in the competitive struggle. T principle of respect for the rules of the game was essential for Allais and applied to politics as well as to economics. He wrote that in economics "the game of competition requires a legal order capable of effectively opposing monopolistic tendencies" (1950c, p. 573). It is this analogy between politics and economics that gave rise to Allais's concept of economic democracy, which he referred to as "a system in which the most equal distribution of income possible is achieved among all those who do not compromise the maximisation of real average income, that is, who ensure the maximisation of social output" (1947c, p. 2). The realisation of economic democracy presupposed the fulfilment of a double condition: on the one hand, the maximisation of the average real income and, on the other hand, the realisation of the most equal distribution possible. This approach was based on two important results: (1) the economic theory demonstrates (Allais, 1943) that the average real income is maximum in the framework of a price-based market economy in which the supply and demand of autonomously and freely managed companies confront each other according to the competitive principle. This result applies equally to both a private economy and a collective economy; (2) the most equal distribution of income possible implies the abolition of all income that is not directly related to an effort made or a service rendered. It is a question of suppressing the inflationary profits of monopolies and the collective appropriation of rents of scarcity (in particular land rents and the pure interest of capital).

Insofar as this approach was accepted, Maurice Allais insisted on the following three points. Firstly, any economic system must be organised according to the principle of competition, i.e. based on the free choice of individuals and the management autonomy of firms. If the competitive economy is primarily "an economic technique" that leads to an optimum level of management, he argued, price stability, "appears to be a necessary precondition of all effective competition" (1946c, p. 2). Secondly, the intervention of the (federal) state is necessary in order to eliminate monopoly profits and scarcity rents (their taxation were to serve as resources for the federation). This double result implies the absence of any class or nationality privilege (possibility of free emigration and free immigration internationally) and equal opportunities in a competitive economy. Thirdly, he wrote, "Only decentralised planning, i.e. competitive planning of the economy, is compatible with democracy, and this irrespective of whether the property regime is capitalist or collectivist" (1950c, p. 571). Democracy would be incompatible with central planning (symbolising the concentration of power) and the presence of monopolies (such as closed groups or class monopolies). Federal Europe, via the criterion of economic democracy and the principle of competitive planning, would thus constitute a third alternative, a middle-way between American laissez-faire and Soviet authoritarian planning.

\section{Economic and Monetary Integration}

From a federalized Europe, it was only a short step to the question of its economic and monetary integration. Two articles written in 1949, "The Westminster European Conference and the Economic Problems of Europe" and "The Social Problems Posed by the Economic Union of Europe and their Solutions" insisted on both the achievement of total freedom of movement of goods, services, capital, and people within the larger European market, and on the introduction of a single currency. In the purest tradition of the economic engineer-economists, Maurice Allais relied on both the lessons of facts and the results of economic theory to legitimise his views on European integration.

\subsection{The Achievement of a Single Market}

Although Allais believed that political integration was a necessary condition for the creation of a common market (Allais, 1951a), he also maintained that this alone was not sufficient. He referred to three other conditions, which were just as important: a general liberalisation of the economy (Allais, 1953a, 1972); the market economy and the principle of competition, and the search for a synthesis between the 'action technique' of liberalism and the ideals of socialism.

\subsubsection{A General Liberalisation of the Economy}

In terms of both analysis and applied economics, the work of Maurice Allais sought to rethink the role of economic freedom (Diemer, 2009b, p. 43) at a time when the doctrinaire field (liberalism, Keynesianism, and Marxism) and the content of economic policies (liberal vs. planning economy) were being debated among economists (Dard, 2000, p. 77). Allais argued that general liberalisation of the economy was a necessity for Europe: "If the West is to survive, it must of necessity maintain, strengthen and extend economically the system of a free economy, based on decentralised decision-making and the maximum use of individual initiative and effort, which has enabled it to achieve an 
unprecedented and continuous increase in its standards of living and cultural opportunities" (1960a, p. 14). Europe, he declared, has to take the form of a free economy and a common market in which there are no barriers to the movement of goods, capital and people, in which there are no tariffs or quotas, in which currencies are freely convertible and capital can be freely invested where it is most profitable, and in which workers can settle and work where they please (1960a, p. 20).

The transition to free trade in goods within a common market implies a considerable change in industrial location and specialisation (international trade theory), i.e. the growth of some activities and the decline of others. Allais was aware that a European Union would pose many social problems, considering that "one could not entrust oneself unreservedly to the application of market mechanisms by a brutal and automatic lowering of customs barriers" (1960a, p. 147). It was therefore necessary to provide for the possibility of reducing the pace of the achievement of economic union by a possible decrease in the rate of trade liberalisation. Allais advocated for fixing this rate according to the volume of technological unemployment observed in the different countries (each of them naturally having the possibility of adopting a higher or lower rate) and to accompany this 'painful' transformation of Europe by adequate measures: sufficient unemployment benefits, professional re-education of the unemployed that included full salaries, bonuses to facilitate changes of profession and residence, and substantial redundancy payments (Allais, 1949e, 1960a). The liberalisation of capital movements, according to Allais, would be easier to put in place than the liberalisation of the movement of goods. It seemed essential to level out the differences in productivity and real wages (between the United States and Europe) and to allow the realisation of a European management optimum (capital inflow to allow investment in the Common Market). Finally, Allais believed that the liberalisation of people should only be undertaken once the effects of the liberalisation of the movement of goods and capital were fully felt. Allais (1950c, 1953g) added that it would be difficult to envisage the mobility of people in Europe until a common policy on immigration, naturalisation, and political asylum had been defined. Thus, he argued, the issue of immigration from Eastern Europe, the former Soviet republics, Africa and South East Asia "will dominate the foreseeable future" of Europe (1994, p. 27). In the end, the transition to Economic Union and the Common Market had to be gradual: "The movements of the various factors of production must not be liberated too quickly, they must be liberated sufficiently quickly so that continuous pressure can be exerted effectively on the various economic agents" (1960a, p. 123). Allais (1949g, 1960a) even presented a number of guiding principles that could avoid any unbearable social disorder. These were the principles of adjustment (liberalisation of quantitative restrictions on the movement of goods within a few months, with complete liberalisation only in 10 or 20 years; liberalisation of capital movements within a few months, at least for current payments; immediate liberalisation of the movement of persons where possible, otherwise a longer period would be required); principles of distribution (all people should be guaranteed the risks they are likely to run, the measures taken should not have the effect of lowering real wage levels); and principles of implementation (while new industrial specialisations and locations should be based on market price indications, some powers could be given to an international authority to judge the requirements of the states).

Allais drew on the lessons of the Steel and Coal Community (ECSC), Britain's Free Trade Area project (1956), the Common Market Treaty (1958), and the Small Free Trade Area of the Seven (1959) to present his vision of liberalisation. In the case of the ECSC, Allais recalled that the results obtained between 1953 and 1957 were much more limited than is often stated (ECSC, 1963). First of all, the ECSC benefited from a favourable economic climate until 1957, while 1958 was marked by a clearly unfavourable economic environment (ECSC, 1958) and the rise in stocks (nearly 30 million tonnes). Thereafter, no fundamental transformation of the structure was visible. In the absence of any political integration, the powers of the High Authority were always limited (Allais, 1959) by the opposition of several states or of a single state (Articles 71 to 73 of the Treaty reserving to the states the commercial policy from outside). Finally, Allais pointed out that there was a desire to "create a particular common market while at the same time there was no general common market" (1960a, p. 173). Prices were far from being competitive (Allais, 1951b). In application of the Treaty, some countries (including France) had to give up the right to set steel and coal prices authoritatively (Saint Marc, 1961), but they continued to retain control over prices by setting those of finished and semi-finished products. Moreover, the conditions of competition within the ECSC had never ceased to be dominated by exchange rate values. On the Treaty side (1958), Allais (1960a, 185-190) insisted on the progress of Article 3 (mentioning the realisation of an effective common market), Articles 85-102 (establishing the rules for the functioning of a market economy) and Article 137 (providing for the members of the European Assembly to be elected by universal suffrage), while underlining the Treaty's essential shortcomings, in particular the inadequacy of the supranational character of the institutions (the non-existence of a political Europe), the numerous derogations from the liberalisation of goods contained in Articles 95 , 96 and 97 (exemptions and rebates granted to exported products, excise duties, indirect taxes), Articles 38 and 39 relating to agriculture and the uncertainty surrounding the liberalisation of capital movements (Art. 67 on the transition period), the application of the provisions associated with the liberalisation of the movement of persons (Art. 48 mentioning that free movement is subject to reasons of public order and public security), and the existence of a very large number of questions referred to in a later regulation (Art. 63 on the liberalisation of services, Art. 75 concerning transport, Art. 87 referring to the rules of competition... ). If the 1956 project of the Free Trade Area of Great Britain and the creation in 1959 of the 
Small Free Trade Area of the Seven (Austria, Denmark, Great Britain, Norway, Portugal, Sweden, Switzerland) could compromise the effective realisation of the Common Market of the Six (Bossuat, Fleury, 2001), Allais argued in favour of the extension of the latter to the Atlantic framework. Despite the existence of certain difficulties, the economic advantages of such a connection would be undeniable: "Firstly, the larger the scale of liberalisation, the easier it is to find compensation. Secondly, and in monetary terms, it is in my opinion easier to operate an Atlantic international monetary system than a purely European one " (1960a, p. 14).

\subsubsection{Market Economy(S), Law of Supply and Demand, Competition}

The strength of the market economy and the principle of competition take on a double dimension in Allais's work. On the one hand, study of the facts - more precisely the standards of living and productivity between Europe, the Soviet Union, and the United States - highlighted the efficiency of the market economic system (Allais, 1960a). On the other hand, economic theory would reveal that the economic integration of the different European states could only be achieved on the basis of maximising real national income at the European level. The social efficiency theorem (Allais, 1943, 1945a) - the cornerstone of Allais's work - implies the presence of a market economy (then markets), the principle of supply and demand, and competition.

The efficiency of the market economy appeared in Allais's applied economics work following several studies comparing living standards and productivity between the United States, Europe (France, Italy), and the Soviet Union (Allais, 1949j, 1949k, 1949l, 1950d). Estimating for the year 1957 that the average hourly productivity in the United States was about 2.34 times higher than in France, Allais sought the causes of this gap and identified five explanatory factors: natural wealth; capital intensity (value of accumulated savings relative to the value of national income); labour (quality of work, volume of the population or extent of the market, demographic expansion and social promotion); the economic system (competition or dirigisme); and the spirit with which this system was applied. He deduced that "the three main explanatory factors of the differences in productivity observed between France and the United States are natural wealth (15 to $20 \%$ ), the technical effect of size (10\%), and finally the effect of an efficient functioning of the market economy (75\%)" (1960a, p. 53). Thus, for Allais, the creation of a Common Market owed less to the size effect than to the competitive process. Indeed, he argued that market constraints and the need to lower prices to meet competition were the by-products of the market economy. American superiority came to a very large extent from the competitive system that characterised it.

On the other hand, the conditions of efficiency of the Common Market were identified with the conditions of maximisation of real national income at the European level. This is where the Allaisian theory of social efficiency or the theory of maximum efficiency (today referred to as optimal allocation of resources) comes in. Allais (1945a) intended to demonstrate that, for a given distribution of consumable services among different individuals, there was one and only one optimal management of the economy for which the return is maximal and that in its essential principles, this management derives directly from the competitive economy. To this end, he distinguished two sectors in the economy. Firstly, the differentiated sector (mining, iron and steel production) corresponding to "those industries where the optimum technique of production is achieved by the juxtaposition of different enterprises which are generally of the same size" (1945a, p. 16). Thus, wherever competition is physically possible (i.e. independent of any consideration of price and of any management methods: competition, monopoly, monopolistic competition, etc.), Allais laid out conditions for maximum efficiency as follows (Allais, 1960a p. 70): (1) there must be a single price system, the same for all buyers and sellers for comparable transactions (principle of price unicity and non-discrimination). This price system must be such that the overall value of supply is equal to the overall value of demand for any product (principle of equalisation of supply and demand by price); (2) each consumer must freely distribute his income between the various possible goods and services, taking into account their prices, and buy where the price he pays (delivered price equal to the initial price plus the cost of transport) is the lowest possible for the same quality (principle of consumer freedom); (3) each seller must sell at the highest possible price (principle of producer freedom); (4) each producer must choose his production technique in such a way as to achieve the maximum income, taking market prices as a given in his calculations (principle of profitability). Thus, where competition is physically possible, a situation of maximum social return corresponds to an equilibrium of perfect competition. The undifferentiated sector corresponds to industries where the optimum production technique is carried out by a single company (gas distribution). Where competition is not physically possible, maximising social efficiency requires: (1) a price equal to marginal cost such that all output finds takers; (2) minimising average cost.

The practical lesson to be drawn from the social efficiency theorem for European economic integration today is that "full efficiency of the economy of a group of countries can only be achieved on the threefold condition: a) that all customs barriers (tariffs or quotas) are removed (in application of the principles of price uniqueness, non-discrimination, and freedom); b) that the price system used is that of a market economy; and c) that these two conditions are realised within each national framework" (Allais, 1960a, p. 71). If the market economy, via the principle of supply and demand and the competitive mechanism, should promote the efficiency of the European economy, Allais was nevertheless aware of the 
limits of this postulate. Firstly, if competition is desirable, the question is whether it is actually possible (if competition can be practised, Allais recommended imposing quality labels to guarantee the quality of goods) and humanly bearable (need for sufficient unemployment benefits for workers). Secondly, trade liberalisation is only possible, as he argued, "within the framework of regional groupings, grouping together countries that are economically and politically associated, of comparable economic development, while ensuring a sufficiently large market for competition to develop in an effective and beneficial manner" (2005b, p. 87). What is now termed "trade globalization" could create irreparable damage in terms of jobs, growth, and industrial specialisation (Allais, 1999a and 1999b). The implementation of a moderate but effective protective system would therefore be considered desirable whenever the need to stabilise and secure certain fundamentals is felt. Europe could thus resort to Community preference when countries had much more favourable production conditions (very low labour costs) than those existing in Europe or when prices on international agricultural markets were unstable. According to Allais, a reasonable objective would be that, through appropriate measures and for each product or group of products, a minimum percentage of Community consumption should be provided by Community production: "The average value of this percentage could be around 80\%" (2005b, p. 87). Thirdly, the implementation of a decentralised market economy and private ownership might be very delicate for countries that decided to join the Economic and Monetary Union. This message, which is particularly relevant today for the Eastern European countries and the different phases of European enlargement, would be based on the observation that "the transition phase to a market economy may lead to inflation, unemployment, undue inequalities that are not well supported, and many other difficulties, which can only be eliminated by the efficient functioning of markets over time" (1991, p. 28).

\subsubsection{The Synthesis/Marriage of Liberalism and Socialism}

If the market economy seems to be the most efficient one, it is such above all in comparison with the centralised dirigiste model. Allais believed that the political, economic, and monetary construction of Europe must therefore be inspired by the different systems in place (laissez-faire and market economy in the United States, centralisation and authoritarian planning in the Soviet Union), while seeking to go beyond them. Allais (1946a, 1947e, 1949b, 1949c, 1950a, 1950b, 1950c, 1960a) described this third model as a synthesis of liberalism and socialism: "The economic and social organization that will emerge from this transitional phase will identify itself... neither with American capitalism nor with Soviet communism... it will borrow from liberalism its extraordinarily efficient technique of decentralized management based on competitive prices and from Marxism its high concern for social justice" (1949b, p. 1). It would certainly be possible to conceive of a centrally planned organisation of the whole of Europe which would be based not on the price mechanism, but on the centralised and authoritarian decisions of a central European body. However, Maurice Allais reminds us that the lessons of theory and experience do not tend to confirm this orientation. On the one hand, economic calculation appears technically impossible, even with the availability of powerful electronic machines, "because we do not know the functions of satisfaction which characterise individual psychologies and the functions of production which characterise production techniques " (Allais, 1960a, p. 72). On the other hand, central planning is not politically acceptable because "it inevitably leads to the conception of all economic power in the hands of political power... The dirigiste technique of central planning leads ineluctably to a totalitarian system" (Allais, 1960a, p. 73). Finally, Allais declared that experiments with such organisation in national settings (Shonfield, 1967) have raised such difficulties "that it is unlikely that an experiment on a European scale would have any chance of success" (Allais, 1960a, p. 125). On this last point, Allais attributed the abandonment of central planning in the Netherlands (1947-1948) to their willingness to join the Benelux Economic Union.

The social aspirations of European citizens had to take place in a market economy based on economic freedom and competitive prices. More specifically, he argued that the structures in which the market economy operates must be planned in such a way that the fundamental objectives of social justice are achieved within the framework of such an economy. Indeed, the stimulus of competition, long considered as "essentially linked to the play of self-interest in a regime of laissez faire" (1946b, p.1), is neither spontaneous nor automatic. It can only exist within the framework of the law, competitive planning (Allais, 1946a), or competitive socialism (Allais, 1947e). This last expression alone symbolises Maurice Allais's vision for society. If the market economy and private property appear to be essential conditions of any free society, "Only those men whose social aspirations are in their very foundations those of the parties of the left can succeed in implementing it effectively" (1949b, p. 7). A liberal Europe, in the hands of social forces was what Allais advocated. Socialists must strive to reform society in such a way as to achieve the ends to which they aspire, but without destroying or undermining the mechanisms of the decentralised market economy and private property. As Allais put it: "The ends of socialism are the maximum liberation of the individual from the constraint of men and things, the abolition of social injustice, the collective appropriation of unearned income, the abolition of all class divisions, the social advancement of the best, and the establishment of a peaceful international order" (1960a, p. 321).

\subsection{From Common Currency to Financial Crises}

Although economic integration was a decisive step in the construction of Europe, Maurice Allais always maintained that it 
could not be completed without price stability and the creation of a single currency. As early as 1946 and 1949, he wrote, « The competitive economy is and remains the only economic technique that can lead to an optimum of management, but price stability appears to be the necessary precondition for the establishment of any effective competition » (1946b, p.2). "The monetary problem was one of the most important, and for the immediate future certainly the most important, because it conditions all the others. The resolution which was adopted [at the Westminster Conference] advocates the free convertibility of European currencies, after a transitional period during which the present exchange rates are revised and exchange demands are limited to current transactions. Such a solution essentially implies the maintenance of exchange controls vis-à-vis non-European countries. The final goal is the creation of a single currency for the whole of Europe" (1949e, p. 6).

The single currency and the various issues related to its creation and circulation are an illustration of Maurice Allais's fights for Europe (1991, 1994, 1998, 2002). First of all, Allais argued that the management of the European currency and the implementation of the common monetary policy should be entrusted to the European Central Bank (ECB), whose main objective would be to ensure reasonable stability of nominal prices expressed in euro, corresponding to an annual rate of increase of around 2\% of the general level of European prices. According to Allais, this stability was an essential factor in the prosperity of Federal Republic of Germany and would protect the European economy from inflationary pressures (Allais, 1969). However, for this to happen he argued that the European Central Bank must be independent of political power, whether national or European: "The European Central Bank should have absolute control over and full and indivisible responsibility for European monetary policy, excluding absolutely any possibility of partial transfer of power to national Central Banks..." (1991, p. 84). It is due to the adoption of such measures that today, no European state is able to finance its public deficits through monetary creation (a Keynesian policy long opposed by Allais). Today a member state can finance its budget deficit by calling on public savings. This involves issuing securities (treasury bills) onto the financial market. Although Allais was a supporter of the euro, he did not hesitate to distance himself from the decisions of the European monetary authorities. The introduction of a single currency on 1 January 1999 was, in his view, a "truly exorbitant... and totally unacceptable demand" (1994, p. 43).

Secondly, Allais argued that the introduction of the euro would have to be accompanied by genuine reforms to make monetary integration viable. According to Allais, today's world economy is based on gigantic pyramids of debt (the net financial position of the United States vis-à-vis the rest of the world is a debtor of $\$ 2,100$ billion, and the cumulative current account deficits exceed $\$ 6,000$ billion). The result is a potentially unstable situation and the multiplication of financial crises since the beginning of the 1970s (from 1971 to 2008, the world economy has recorded almost 26 financial crises). The origin of financial crises is linked to three mechanisms (Boyer, Dehove, Pilhon, 2004).

The first mechanism is specific to financial markets, which are markets of promises (the value of a financial asset depends on an agent's evaluation of a future income stream), and are subject to major uncertainties. Faced with uncertainty, agents must adopt procedures, rules, or conventions to evaluate interest rates, expected growth, the risk premium, etc. Two methods can be used: (1) carry out one's own value analysis, (2) observe the valuation of others (mimicry logic). In the latter case, a pattern of financial contagion may emerge and create a speculative bubble.

The second mechanism concerns the pro-cyclical nature of risk-taking. The risk premium measures the difference between the market price and the fundamental value of an asset. During the expansion phase, banking and financial agents would tend to take more risks (because the risks are low), whereas during the recession phase, they would tend to overvalue the risks. Pro-cyclical risk-taking would thus explain the alternating phases of euphoria and stress at the heart of the financial and market crisis (credit, financial assets, real estate assets, etc.). The behaviour of economic agents would have a destabilising effect, thereby amplifying the economic cycles (this is known as the financial accelerator).

The third mechanism is based on the interdependence of markets. Any imbalance in one market leads to a crisis in the other markets. Following financial globalisation and the 3Ds (deregulation, disintermediation, decompartmentalisation), this process of financial contagion now has a global dimension. The various markets (credit, shares, bonds, real estate, etc.) are irremediably linked. This is also known as systemic risk. These market jolts are generally aggravated by the mimetic behaviour of financial agents, the loss of memory of previous events, or the excessive optimism of certain players.

Financial crises are all the more serious as all the risks tend to be concentrated on the banks (e.g. the recent subprime crisis). This systemic scenario had already been highlighted by Allais in his book Europe and its Future: What to Do? (1991) in which he wrote that "the increasing monetisation of debts, monetary deregulation, and the implementation of new financial instruments have only one result: the increasing instability of the banking system at the national and international levels" (1991, p. 104). In order to deal with the emergence of a new crisis, Allais called for a reform of the credit system, an indexation to future commitments, a reform of the stock markets, and a reform of the international monetary system.

To Allais, the contemporary organisation of credit appeared completely irrational for six reasons: (1) the irresponsible 
creation and destruction of money based on the decisions of banks and individuals; (2) the very great sensitivity of the credit mechanism to the economic situation; (3) the instability of the land which credit engenders; (4) the alteration of the conditions of maximum efficiency of the economy; (5) the alteration of the distribution of income which are the consequences of the latter?; and (6) the impossibility of any effective control of the credit system by public opinion and the European Parliament because of its extraordinary complexity. Moreover, in his view, two factors amplified the disorder: (1) the creation of money ex-nihilo by the credit mechanism (at each credit operation, there is monetary duplication: the holder of a deposit considers it as available cash while at the same time the bank has lent most of this deposit); and (2) the financing of long-term investments by short-term borrowed funds. Allais considered necessary a credit reform based on two principles. First, the creation of money should be the responsibility of the State. In his view, any monetary creation by the Central Bank other than basic money should be made impossible. Second, in practice, a profound modification of banking and financial structures should allow for a total dissociation of banking activities into three categories of institutions: "Deposit banks ensuring only, to the exclusion of all lending operations, the collection, payment and safekeeping of their clients' deposits; loan banks borrowing at given terms and lending the borrowed funds at shorter terms; [and] business banks borrowing directly from the public or from the loan banks, and investing the borrowed funds in enterprises" (1991, p. 106).

The indexation to future commitments insists on the fact that all contracting parties (whether debtors or creditors, entrepreneurs or employees) must be protected against changes in the purchasing power of the unit of account. A compulsory real value indexation of all commitments in the future would tend to make it impossible to distort prices and incomes. It would imply "a legal obligation to link all future medium and long-term loans of the state, companies and households to a guarantee of purchasing power, principal and interest" (Allais, 2002, p. 104).

For their part, the stock markets had become veritable casinos «where the gaming tables are spread over all longitudes and latitudes » (Allais? 1991, p. 222). The different stock markets would move according to waves of optimism and pessimism. As a result, the markets would no longer provide an institutional framework conducive to investment. Worse, the system would be on the verge of becoming uneconomic. In order to make the financial markets useful again, Allais suggested a series of reforms such as the abolition of the continuous quotation of prices (replaced by a single quotation per day for each security) and the abolition of speculation on indices. While in principle, speculation is necessary for the market (it generates liquidity), the behaviour of speculators (buying without payment, selling without holding assets) is destabilising. Allais considered it possible to control speculative capital movements; in his view, all that is needed is for the major nations to establish international legislation prohibiting banks from speculating on their own behalf.

Finally, the international monetary system was said to be corrupted by the instability of floating exchange rates, persistent imbalances in the balance of payments (mainly that of the United States), the development of unbridled speculation, and the supremacy of the dollar. Among the reforms advocated by Allais were the prohibition of all competitive devaluations, the abandonment of the dollar as a currency of account, as a currency of exchange, and as an international reserve currency, the merging of the World Trade Organisation and the International Monetary Fund into a single body, and the prohibition of banks from speculating on foreign exchange or for their own account.

In practice, these measures have found some traction at the institutional level. Since the introduction of the euro, with European monetary policy managed by the ECB, it is no longer possible to play on currencies to improve the competitiveness of national companies. This measure has salutary virtues, as it forces companies to seek competitive advantage by playing on price competitiveness (productivity efforts) and/or structural competitiveness (quality, innovation, flexibility, organisation). Although exchange rates are fixed within Europe, the euro continues to evolve according to the buying and selling of currencies (dollar, yen, Swiss franc, etc.). Consequently, any rise in the $€ / \$$ exchange rate can be interpreted as a US desire to let the dollar go in order to improve its trade balance with Europe. While trade transactions continue to favour the dollar as an invoicing currency, a settlement currency, and a reserve currency (the dollar accounts for two-thirds of the reserves held by central banks), the euro comes in second place with $25 \%$ of the world's reserves in euro in 2007 (compared to 18\% in 1999). Since 2003, there have been more international bond issues denominated in euro than in dollars. Since April 2007, there are more euro banknotes in circulation than dollar banknotes. Finally, China and a large share of the banks of emerging countries have gradually abandoned the pegging of their currencies to the dollar. While the merger of the IMF and the WTO is not on the agenda, some voices do not hesitate to call for a reform of these institutions. Certain governance problems have been raised: modification of the distribution of voting rights (representatives of rich countries currently control more than $60 \%$ of voting rights at the IMF), questioning the right of veto of the United States on decisions that require a super-majority, more transparency of the positions adopted by member countries, delimitation of areas of action (particularly with the World Bank), more voluntary action in crisis management... The ban on banks speculating on foreign exchange or for their own account is perhaps the most delicate reform to implement. Contrary to popular belief, the development of financial markets has not sounded the death knell for banks. In addition to their deposit-taking and lending operations, banks have developed intermediation activities on the 
financial markets. We are, therefore, far from the wave of disintermediation some warned of the 1980s. The systems have become hybrid and banks have been able to evolve with the development of the financial markets. Competition has led to the emergence of large banking groups, commissions on market operations represent a significant part of their gross income, financial innovations - securitisation and derivatives - have made it possible to reduce the cost of capital and transfer risks to the markets, and the regulatory authorities still have great difficulty in supervising commercial banks, etc.

\section{Conclusion}

A proponent of a certain social liberalism or liberal socialism, Maurice Allais devoted a large part of his life and work to the European question. In the purest tradition of the engineer-economists, this Nobel Prize Laureate in Economics endeavoured to combine pure and applied economics in order to bring compelling arguments to a debate that is too often marked by bias and prejudice. A staunch Unionist, Maurice Allais reminded us as early as 1945 that, while the threefold freedom of goods, people, and capital was necessary to improve the well-being of individuals, it was also a very ambitious goal. Consequently, he argued, it was necessary to forge a federal Europe on the basis of a scientific criterion-economic democracy — and a sound method - competitive planning. However, Allais was aware that political integration had to precede economic integration, and that the latter could not ensure economic efficiency without a single currency. This is why, in his view, the introduction of the euro had to be accompanied by real monetary reform (credit system, indexation of commitments to the future, stock markets, international monetary system) intended to mitigate the multiplication of financial crises. European integration, Allais argued, must be pursued solely on the basis of competition, an essential condition for economic efficiency and social justice. While this approach may leave little manoeuvering room for individual national governments, it is the price to be paid for improved management of public administration.

\section{Acknowledgments}

This research was funded by the ERASMUS + Programme of the European Union (Jean Monnet Excellence Center on Sustainability, ERASME).
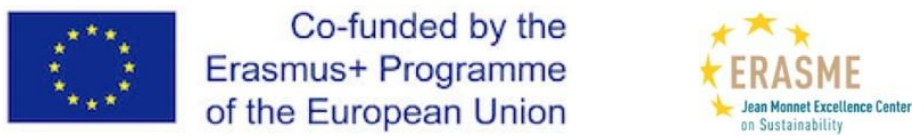

\section{References}

Allais, M. (1943). A la recherche d'une discipline économique. Première partie, L'Economie Pure. Première édition, Ateliers Industria, 2 vol. 852 p et 68 p. Deuxième édition, éditée sous le titre : Traité d'économie pure, Imprimerie Nationale et Centre National de la Recherche Scientifique, 1952, 5 vol, in-4º 1000 p. Troisième édition, 1994, éditions Clément Juglar.

Allais, M. (1945a). Economie pure et rendement social. Editions Sirey.

Allais, M. (1945b). Prolégomènes à la reconstruction économique du monde. Editions Sirey.

Allais, M. (1946a). Abondance ou Misère. Paris, Librairie de Médicis. 120 p.

Allais, M. (1946b), Quelques réflexions sur l'Inégalité, les Classes et la Promotion Sociale. Economie et Humanisme, juillet-août, p. 357-374, septembre octobre, 484-499.

Allais, M. (1946c). Deux conditions fondamentales d'un jeu efficace de la concurrence, la suppression du laisser-faire et la stabilité monétaire. Bulletin des transports et du commerce, août, 2 p.

Allais, M. (1946d). Le problème de la coordination des transports et la théorie économique. ENSMP, réf 67.567 CCL $5083,27 \mathrm{p}$.

Allais, M. (1947a). Note sur notre terminologie économique. Groupe de recherches économiques et sociales, Paris, ENSMP, le 21 janvier, 3 p.

Allais, M. (1947b). Economie et Intérêt, Imprimerie Nationale.

Allais, M. (1947c). Les aspects économiques du fédéralisme. Rapport présenté au Congrès de l'Union Européenne des Fédéralistes, Montreux, Août, 34 p.

Allais, M. (1947d). Coordination des transports, le problème de la coordination des transports et la théorie économique. ENSMP, réf 71.709 CCL 1121, 32 p.

Allais, M. (1947e). Pour un socialisme concurrentiel. La Fédération, septembre, 12 p.

Allais, M. (1948a). La révolution européenne reste à faire. Ecole Nationale Supérieure des Mines de Paris, réf EMP 70.605 - CCL 1129. 
Allais, M. (1948b). Les problèmes économiques et sociaux de l'heure et leur solution. Ecole Nationale Supérieure des Mines de Paris, réf EMP 71.747 - CCL 1122, 9 p.

Allais, M. (1948c). Le problème de la coordination des transports et la théorie économique. Sirey.

Allais, M. (1949a). Projet de Manifeste économique et social pour les Etats-Unis d'Europe. Groupe de Recherches économiques et sociales, Paris, le 14 janvier, 13 p.

Allais, M. (1949b). Concurrentialisme et marxisme. Groupe de recherches économiques et sociales, Paris, ENSMP, le 20 avril, $16 \mathrm{p}$.

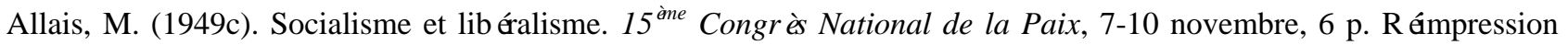
dans les Cahiers Socialistes, Bruxelles, mai, 31-37.

Allais, M. (1949d). Union européenne ou Union atlantique. Groupe de recherches économiques et sociales, Paris, ENSMP, le $1^{\mathrm{er}}$ juin, $6 \mathrm{p}$.

Allais, M. (1949e). La Conférence européenne de Westminster et les problèmes économiques de l'Europe. Groupe de recherches économiques et sociales, $\mathrm{n}^{\circ}$ 1948-0-3, 3 juin, $22 \mathrm{p}$.

Allais, M. (1949f). Les Problèmes de l'Union Economique de l'Europe. Travaux du Congrès des Economistes de Langue française, Editions Domat-Montchrestien, 176 - 198.

Allais, M. (1949g). Les problèmes sociaux posés par l'Union économique de l'Europe et leurs solutions. Bulletin des Transports, Commerce - Economie Politique, octobre, 688-699.

Allais, M. (1949h). Les Unions Douanières et l'Unification Fédérale de l'Europe. Etudes économiques, ISCCP Mons, octobre, $15 \mathrm{p}$.

Allais, M. (1949i). Note sommaire sur le problème des investissements. Groupe de Recherches économiques et sociales, Paris, ENSMP, le 7 novembre, 4 p.

Allais, M. (1949j). Pouvons-nous atteindre les hauts niveaux de vie américains. Revue des Ingénieurs, novembre décembre, 5-18.

Allais, M. (1949k). Productivités, salaires réels et Union Economique. Economia Internazionale, août, 615-629.

Allais, M. (19491). Les niveaux de vie européens et américains et l'Union économique de l'Europe. Le Hainaut Economique, septembre, 191-201.

Allais, M. (1949m). Les Unions douanières de l'Europe. Ecole Nationale Supérieure des Mines de Paris, réf EMP 71.394, CCL 1108, 15 p.

Allais, M. (1950a). Au-delà du laisser fairisme et du totalitarisme. Nouvelle Revue d'Economie Contemporaine, avril, 25-32.

Allais, M. (1950b). Au-delà du laisser fairisme et du totalitarisme. Nouvelle Revue d'Economie Contemporaine, mai, 26-32.

Allais, M. (1950c). La démocratie et le totalitarisme. Ecole Nationale Supérieure des Mines de Paris, Leçon 50, document 503, 569-585. Texte publié dans la Revue d'Economie Contemporaine, novembre - décembre 1950, 8-17, janvier 1951, 7-17.

Allais, M. (1950d). L'économie soviétique est-elle efficiente? Nouvelle Revue d'Economie Contemporaine, octobre, 4-12.

Allais, M. (1950e). La libéralisation des mouvements de personnes est-elle possible en Europe ? Nouvelle Revue d'Economie Contemporaine, 1, janvier, 4-7.

Allais, M. (1950f). Les intérêts des groupes sociaux et nationaux et l'Union économique de l'Europe. Imprimerie nationale, réf EMP 71.625, CCL 1355.

Allais, M. (1950g). La libération des mouvements de personnes est-elle possible en Europe ? Librairie de Médicis.

Allais, M. (1950h). Peut-on assurer la sécurité de l'Europe et gagner la guerre froide. Nouvelles Editions Latines.

Allais, M. (1951a). L'Union politique, condition première de toute union économique. Annales des Mines, vol II, 7-13.

Allais, M. (1951b). La gestion des Houillères Nationalisées et la théorie économique. Imprimerie Nationale, Paris.

Allais, M. (1952). Les voies fécondes de la théorie économique. Nouvelle revue de l'économie contemporaine, 36, décembre, 4-6.

Allais, M. (1953a). La libéralisation des échanges commerciaux en Europe, Camera di Commercio, Industria e 
Agricultura, $35 \mathrm{p}$.

Allais, M. (1953b). La libéralisation des services commerciaux en Europe. Chambre de Commerce de Marseille, 20 p.

Allais, M. (1957a). Un marché commun atlantique est-il ou non une utopie ? Ecole Nationale Supérieure des Mines de Paris, réf EMP 134.409, CCL 1362-1.

Allais, M. (1957b). La politique économique atlantique. Revue Politique et Parlementaire, in Ecole Nationale Supérieure des Mines de Paris, réf EMP 120.836, CCL 1122.

Allais, M. (1959). Le Traité de la Communauté Européenne du Charbon et de l'Acier doit-il être modifié ? Ecole Nationale Supérieure des Mines de Paris.

Allais, M. (1960a). L’Europe Unie, Route de la Prospérité. Calmann-Lévy.

Allais, M. (1960b). Manifeste pour une Société Libre. Ecole Nationale Supérieure des Mines de Paris, 72 p.

Allais, M. (1964a). Options de la politique tarifaire dans les transports. Rapport de la Commission de la Communauté Economique Européenne, 485 p.

Allais, M. (1964b). La théorie économique et la tarification optimum de l'usage des infrastructures de transport. Groupe de recherches économiques et sociales, ENSMP, 134.282 CCL 5162.

Allais, M. (1964c). Prolégomènes pour le maintien et le renforcement de la cohésion de la Communauté Atlantique. Ecole Normale Supérieure des Mines de Paris, réf EMP 125.382 CCL 1337, 54 p.

Allais, M. (1965a). Options de la politique tarifaire dans les transports. Etudes de la Commission des Communautés Européennes, $205 \mathrm{p}$.

Allais, M. (1965b). Plan pour une réforme du système monétaire international. Ecole Nationale Supérieure des Mines de Paris, réf 125.609, CCL 1355, 9 p.

Allais, M. (1966). « Growth without Inflation », Il Politico, Université de Pavie, 1967, Anno XXXII, 2, 348-354.

Allais, M. (1967). Manifeste pour une Société Libre. Centre d'Analyse Economique, 72 p.

Allais, M. (1969). L'ordre international et l'économie de marchés. Institut Universitaire des Hautes Etudes Internationales, Genève, 132 p.

Allais, M. (1970). Capitalisme et collectivisme. Le libéralisme, $3^{\text {ème }}$ séminaire de la pensée libérale, novembre, 93-107.

Allais, M. (1972). La libéralisation des relations économiques internationales. Gauthier-Villars, Techniques économiques modernes, $196 \mathrm{p}$.

Allais, M. (1974). Classes sociales et Civilisations. Economies et Sociétés, Cahiers de l'Institut des Sciences Economiques et Appliquées, 43(17), 285-377.

Allais, M. (1976). L'impôt sur le capital et la réforme monétaire. Editions Hermann, Paris.

Allais, M. (1989). La théorie des surplus. PUG.

Allais, M. (1990). Pour la réforme de la fiscalité. Editions Clément Juglar.

Allais, M. (1991). L'Europe face à son avenir : que faire? Robert Laffont - Clément Juglar.

Allais, M. (1992). Erreurs et Impasses de la Construction Européenne. Clément Juglar.

Allais, M. (1994). La politique de libre échange, le GATT, et la construction européenne. Revue d'économie politique, Janvier-Février.

Allais, M. (1997). Combats pour l'Europe : 1992 - 1994. Clément Juglar.

Allais, M. (1998). L'Union européenne, la mondialisation et le chômage. Ecole Nationale Supérieure des Mines de Paris, réf 147.360, CCL 1459.

Allais, M. (1999). La Crise Mondiale d'Aujourd'hui. Pour de Profondes réformes des Institutions Financières et Monétaires. Clément Juglar.

Allais, M. (1999). La Mondialisation, la Destruction des Emplois et de la Croissance. L'Evidence Empirique. Clément Juglar.

Allais, M. (2001). La passion de la recherche. Clément Juglar.

Allais, M. (2002a). Nouveaux Combats pour l'Europe : 1995 - 2002. Clément Juglar.

Allais, M. (2002b). Un savant méconnu, Portraits d'un Autodidacte. Clément Juglar. 
Allais, M. (2005a). « La Constitution n'est pas un rempart contre les excès du libéralisme », L'Humanité, 26 mai.

Allais, M. (2005a). L'Europe en crise? Que faire ? Clément Juglar.

Bailey, R. (1969), L'intégration économique en Europe: de la C.E.C.A. a I'A.E.L.E, Paris, Librairie générale de droit et de jurisprudence, $101 \mathrm{p}$.

Barrère, C. (2009). Peut-on penser une démocratie économique ? Revue de Philosophie Economique, 9(2), 50-68.

Blaisse, P. A. (1953). Rapport sur le Marché commun. Mouvement européen-Communauté d'action pour la

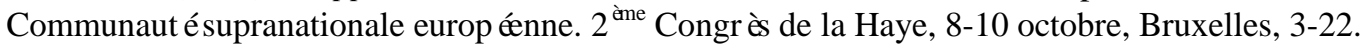

Bossuat, G. (2001). Les schémas français de réorganisation économique de guerre et d'après guerre. Séminaire Milieux économiques et intégration européenne au XXème siècle. Comité Histoire, Ministère des Finances, 11-24.

Boyer, R., Dehove, M., \& Plihon, D. (2004). Les crises financières. Rapport du Conseil d’Analyse Economique, n50, La Documentation Française.

CECA (1963). 1952-1962 : Résultats, limites, perspectives. Haute Autorité. Luxembourg. CECA (1958). Application du Traité Instituant la CECA au cours de la période transitoire. Division études, information et documentation de l'Assemblée Parlementaire Européenne, Luxembourg, 294 p.

Dard, O. (2000). Théoriciens et praticiens de l'économie : un changement de paradigme, in Serge Berstein et Pierre Milza, L'année 1947, Presses de Sciences-Po, 75-114. https://doi.org/10.3917/scpo.berns.1999.01.0075

Diemer, A. (2003). Représentations du marché et démarche de l'économiste. Colloque international ACGPE, Représentations du marché, Grenoble, 25-27 septembre, 30 p.

Diemer, A. (2007). Quel modèle économique et social pour l'Europe : Bilan et perspectives », Colloque international de l'AEILF. Bilan et perspectives d'un demi-siècle de construction de l'Union européenne dans le cadre de la mondialisation économique contemporaine. Varsovie, 21 -23 mai, 25 p.

Diemer, A. (2008). Marché et échange: quelle représentation? in Guillemin H. (ed), Echange, Marché et Marchandisation. L'Harmattan.

Diemer, A. (2009a). Les contributions de Maurice Allais à la question européenne : libres débats. Journée d'études 'Les Contributions de Maurice Allais à la Science Economique’, Maison des Sciences Economiques, Université Paris I, 24 juin, $23 \mathrm{p}$.

Diemer, A. (2009b). Maurice Allais et la science économique. L’Economie Politique, 43, juillet, $100-112$. https://doi.org/10.3917/leco.043.0100

Diemer, A. (2016). La diversité du capitalisme européen. Oeconomia.

Diemer, A. (2020). The Contribution of Maurice Allais to Contemporary Macroeconomics: From French Planning to National Accounting. Theoretical Economics Letters, 10, 334-355. https://doi.org/10.4236/tel.2020.102023

Diemer, A., \& Nedelciu, E. (2020). Competitive planning and Economic Development, the contribution of Maurice Allais Nobel Memorial Prize in Economic Science (1988). Journal of Economics and Development Studies, 8(4), 83 -94. https://doi.org/10.15640/jeds.v8n4a7

Diemer, A., Lallement, J., \& Munier, B. (2010). Maurice Allais et la Science économique. Clément Juglar.

Erhard, L. (1963). Une politique de l'Abondance. Editions Robert Laffont.

Fleury, A. (2001). A propos des options d'organisation de l'Europe non communiste dans les années 50. Séminaire Milieux économiques et intégration européenne au XXème siècle, Comité Histoire, Ministère des Finances, 3-10.

Hayek, F. (1939). The Economic Conditions of Interstate Federalism. The New Commonwealth Quarterly, V(2), September, p. 131-149, in Individualism and Economic Order, chap 12, 1996. University of Chicago Press.

Jennings, W. I. (1940). A Federation for Western Europe. Cambridge University Press.

Keynes, J. M. (1936). The General Theory of Unemployment, Interest and Money. Brace Editions. New York.

Montbrial, T. (2002). Maurice Allais et la construction européenne, in Allais M., Un savant méconnu, portraits d'un autodidacte. Clément Juglar.

Plihon, D., Coppey-Soubeyran J., Saidane D. (2006). Les banques, les acteurs de la globalisation financière. La Documentation Française. https://doi.org/10.3917/ae.254.0074

Robbins, L. (1937). Economic Planning and International Order. MacMillan.

Saint Marc, P. (1961). La France dans la CECA, une expérience de planifications multiples du charbon et de l'acier. 
Paris, Librairie Armand Colin, 456p.

Schumpeter, J. (1947). Capitalism, Socialism and Democracy. London Harper \& Brother.

Servan-Schreiber, J. J. (1949). L'Europe ou l'Atlantique. Le Monde, 30 janvier.

Streit, C. (1939). Union ou chaos. Librairie de Médicis. Paris.

Walras, L. (1909). Ruchonnet et le socialisme scientifique. CEuvres Complètes, VII, Mélanges d'économie politique et sociale. 1987. Economica.

\section{Copyrights}

Copyright for this article is retained by the author(s), with first publication rights granted to the journal.

This is an open-access article distributed under the terms and conditions of the Creative Commons Attribution license (http://creativecommons.org/licenses/by/4.0/). 